\title{
STATE OF RAW MATERIAL BASE OF ELECTRODE PRODUCTION
}

\author{
E.A. PALIEVSKAYA and Z.A. SIDLIN \\ TECHPROM Ltd. \\ 57 Gilyarovsky Str., 107996, Moscow, Russia. E-mail: techprom-ru@yandex.ru
}

\begin{abstract}
State of raw material base in Russia regarding the production of covered electrodes was analyzed focusing on the changes occurred in this field in the recent years. Such categories of raw materials as electrode wire, mineral components of coatings, ferroalloys and liquid glasses were studied. The critical positions on production of single components, search for new sources of raw materials as well as changing conjuncture of materials at the market were mentioned. The conclusion was made that the Russian manufacturers of raw materials still dominate at the domestic market. 9 Ref., 1 Table.
\end{abstract}

Keywords: arc welding, covered electrodes, raw materials, electrode wire, mineral components, ferroalloys, liquid glasses, market

Russia is still the leading European manufacturer of welding consumables, though in 2013 the volume of production of electrodes as compared to the previous year somewhat decreased. However in medium-term prospect, considering the estimated rate of growth of rolled metal at the level of 5-6\% per year, respectively the growth of volume of electrodes production is expected. The composition of enterprises-manufacturers is changed: the volume of Russian enterprises is increased belonging to the largest world producers, in the first turn, ESAB (Sweden) and Lincoln Electric (USA). The enterprises aimed only at the growth of quantitative values, loose consumers and even collapse. At the same time young, ambitious enterprises are being developed, the products of which are oriented to the consumer. The requirements of users towards quality of welding consumables are constantly increasing, the determining values for which (at other equal values) relate to the characteristics of raw materials. If the nomenclature of components used for electrode coatings is very conservative in the whole world (according to the data, for example, of patent studies), then the mineralogical origin and technology of processing of raw materials can influence significantly the properties of electrodes.

In the Soviet times the attempts to increase the quality of products (including also welding consumables) were made at governmental level, in particular through certification according to three categories of quality. However, they were bound to fail both due to total deficiency, as well

() E.A. PALIEVSKAYA and Z.A. SIDLIN, 2014 as due to incorrect methodical approach. Thus, for metallurgy industry the raw materials were excluded from certification, which made all the further efforts hopeless. At the present time the attention to quality characteristics of raw materials changed essentially. The problems of raw materials base of production of welding consumables were considered in detail in the previous works of authors [1, 2], but during the last period of time certain changes occurred, elucidation of which is actually the aim of this publication.

Electrode wire. It is generally known that the quality of welding electrodes depends to a great extent on the welding wire being used. In the domestic practice, to manufacture the overwhelmed volume of electrodes the low-carbon wires of grades $\mathrm{Sv}-08$ and $\mathrm{Sv}-08 \mathrm{~A}$ according to GOST 2246-70 are used. During many years the complains of electrode manufacturers to the manufacturers of a wire were caused by a low quality of its surface, including the presence of rust, contaminations, increased amount of lubricants, bad coiling and packing, difficulties in producing metal with decreased content of sulfur and phosphorus. Though ovality and tolerances of accuracy of diameter correspond to the standard, they do not provide modern requirements for different thickness of electrode coating. During delivery of wire in reels the need in their additional balancing adjustment during unwinding and cutting constantly arose.

Steel and hardware makers performed immense cost effective works on technical re-equipment and reconstruction of plants, which resulted in considerable improvement of quality of wire. At the present time the purchase of wire $\mathrm{Sv}-08 \mathrm{~A}$ does not represent any problems, all wires are delivered in heavy-load bundles with tight winding and binding in the proper packing. In general, 
according to the evaluation of specialists, the quality of domestic rolled wire is inferior to the imported one only as to the state of bundles. For example, after carried out reconstruction the Nizhneserginsky Hardware-Metallurgical Plant produces rolled wire of two-stage cooling of welding wire of grades $\mathrm{Sv}-08$ and $\mathrm{Sv}-08 \mathrm{~A}$ of diameter from $5.5 \mathrm{~mm}$ with the content of $\leq 0.01 \% \mathrm{Al}$, $0.05-0.08 \% \mathrm{C}, \sigma_{\mathrm{t}} \leq 420 \mathrm{MPa}$, with the further manufacture of wire at the Ural plant of precision alloys. The rebreeding of the latter in the NLMKMetiz was carried out in 2013 according to its corporative appertaining and production profile.

At the end of 2013 at the Beloretsk Metal Works the capital repair of rolling mill 150 was finished, where rolled wire is produced of 5.5$14 \mathrm{~mm}$ diameter of carbon, alloyed and high-alloyed steels. Only the problems of providing quality of wire surface, mostly determined by geometry of drawing dies, on the optimal shape of which the presence of tears, defects of surface layers, superhardening depend, were not completely solved [3].

On the surface of a wire, as well as on any other product of drawing production, there is always a certain amount of contaminations of different kind, formed in the process of its manufacture or during storage, transportation, etc. Though GOST 2246-70 admits only the presence of traces of soap lubricant without graphite and sulfur (for high-alloyed wire even they are not admissible) on the surface of low-carbon and alloyed wire, contaminations almost of three groups are found: organic (oils, remnants of technological lubricant, preservation coatings), oxide (rust of all kinds), foreign (mud, dust, occasional substances). For most of the grades of electrodes the use of such wire not only deteriorates their welding and technological characteristics, but also is fraught with defectiveness of welds. At the same time the efficient technologies of cleaning of wire surface during its processing at the electrode enterprises [4] are seldom used.

In the existing GOST 2246-70 the standards to welding-technological properties of wires and their rigidity are absent. But GOST 2246-70 (item 11) contained the standard: «Wire in bundles should be supplied in the state admitting its cutting and straightening»! At the present time in the post-Soviet regions only the national standard of Ukraine on steel welding wire, harmonized with the International standards, envisages the requirements to rigidity and welding-technological properties of the wire. And already in 1997 Krodeks Ltd. and the E.O. Paton Electric Welding Institute developed and implemented the technical conditions for welding wire for mechanized types of welding, nominating the values of its welding-technological properties required by the user [5].

The situation with wires for manufacture of high-alloyed electrodes is much worse. From the most skillful manufacturer of the widest assortment of high-alloyed welding wires: Moscow metallurgical plant «Serp i Molot» with more than 130 years of history, only the territory of 87 ha remained now, intended for multifunctional complex building.

For the plants of special metallurgy the constant difficulties are encountered even to provide the requirements of standards as to the norms of mechanical properties and uniformity of their values within the range of bundle, tolerances for ovality, frequently even in chemical composition. At the domestic market cheap not-welding foreign wires of metal with increased content of harmful impurities, nitrogen, with considerable plus tolerances as to diameters and often with «faked» certificates are already available. Highquality wire of qualified manufacturers at competitive prices is also delivered. The latter passes all the required certificate procedures and is admitted for use by domestic organizations. The successful experience of its use for manufacture of electrodes was gained, that requires, however, extremely high technical level of production. It must be stated that this market for domestic producer was lost to a large extent. Whereas world production of high-alloyed steels is growing continuously by $4-5 \%$ each year, requiring, respectively, welding consumables.

Components of electrode coatings. In electrode coatings the following materials are used in the largest volumes: of non-metallic minerals - marble and fluorspar concentrate (for the coatings of basic type), and of concentrates rutile and ilmenite (for the coatings of appropriate type). Until recently Russia, having in its disposal the considerable reserves of raw materials, has no industrially developed deposits of rutile and ilmenite. The works in this direction are in the process. Thus, in Murmansk region the projecting of an enterprise on production of prospective enriched perovskite concentrate of African deposit of perovskite titanium magnetite ores (joint project of the company «Arkmineral» and Kolsky Research Center of the RAS) is planned. The increased natural radioactivity of material is supposed to be decreased to acceptable level using methods of chemical processing.

At the end of 2013 the successful results of geological prospecting works at the large Pizhem- 
sky deposit of friable titanium in Komi republic were obtained, which alongside with the famous Yargensky deposit make this region very prospective. The corporation VSMPO-A-Visma (the largest world producer of titanium alloys) acquired license on development of large rutile-zirconium deposit Tsentralnoe in Tambov region. Kuranakhsky titanium-magnetite deposit in Amursky region is explored. All these works should be evaluated considering the falling volumes of deliveries of rutile and ilmenite concentrates from the Volnogorsky Mining and Smelting Works (Ukraine), the main supplier of these materials. Unfortunately, all the last years Russian and Ukrainian enterprises were bearing constant and growing difficulties with purchase of these materials. The appeal of Association «Elektrod» to the government of Ukraine on this issue did not have a success. In this connection rutilezirconium concentrate of Sierra Leone, SAR, Vietnam, Australia find ever wider practical application, ilmenite concentrates of India, Sri-Lanka, Mozambique have passed the positive testing. But the concentrate of the Volnogorsky MSW according to its technical characteristics and stability of properties completely meets the requirements of all the producers of electrodes, including European ones and at a reasonable policy of the supplier there would be no need in its change.

The demand on cheap electrodes with ilmenite coating, welding technological properties of which are inferior to the characteristics of rutile electrodes, decreased considerably, respectively the need in ilmenite concentrate also decreased.

Achromous titanium dioxide of rutile modification used in coatings of high-alloyed elec-

Main producers of ferroalloys of Russia [7]

\begin{tabular}{|c|l|c|}
\hline \multirow{2}{*}{ Holding (group) } & \multicolumn{1}{|c|}{ Enterprise } & $\begin{array}{c}\text { Produced } \\
\text { ferroalloys }\end{array}$ \\
\hline \multirow{2}{*}{$\begin{array}{c}\text { ChEMK } \\
\text { ENRC }\end{array}$} & $\begin{array}{l}\text { Chelyabinsk electro- } \\
\text { metallurgical works }\end{array}$ & $\mathrm{FeSi}$ \\
\cline { 2 - 3 } & Kuznetsk ferroalloys & FeCr, FeSi \\
\cline { 2 - 3 } & Yurga plant of ferroalloys & FeSiMn \\
\cline { 2 - 3 } Mechel & Serovsky plant of ferroalloys & FeSi, FeCr \\
\cline { 2 - 3 } & Satka cast iron melting plant & $\mathrm{FeMn}$ \\
\cline { 2 - 3 } & Yuzhuralnikel plant of ferroalloys & $\mathrm{FeSi}$ \\
\cline { 2 - 3 } & Tikhvin plant of ferroalloys & $\mathrm{FeNi}$ \\
\hline \multirow{2}{*}{ Rosspetssplav } & Russky khrom & $\mathrm{FeCr}$ \\
\cline { 2 - 3 } & $\begin{array}{l}\text { Klyuchevsky plant of } \\
\text { ferroalloys }\end{array}$ & $\mathrm{FeTi}$ \\
\hline Evraz & Vanady-Tula & $\mathrm{FeV}$ \\
\hline OMK & Chusovsky metallurgical plant & $\mathrm{FeV}$ \\
\hline
\end{tabular}

trodes, is produced by the STC «Pigment Ltd.» (Chelyabinsk, Russia) since 2012.

The situation with marble, the second material by volumes of its application and the first one by its importance, was improved. Within several last years fractioned micro marble of electrode conditions is supplied by CJSC «Koelgamramor». The supplier reached stability in granulometric composition and humidity of material during deliveries in big-bags with a polyethylene insert.

The critical situation was over fluorspar (fluorite concentrate) [6]. The largest Russian producer of fluorite concentrate «Yaroslavsky Mining Ltd.» (Primorsk region) is capable to produce only concentrate with the content of $\mathrm{CaF}_{2} \leq$ $\leq 92 \%$, its cost is approximately by $30 \%$ higher than that of foreign analogues. Due to these reasons stoppage of the enterprise was planned to carry out its complete modernization. One of the main suppliers of fluorite concentrate for electrode manufacturers is the Haydarkansky Quicksilver (mercury) Works (Kirgizia). At the present time it carries out works on draining of mine «Zapadnaya» to resume the deliveries. The main supplier, the Kalanguysky Ore-Dressing Works (Transbaikal region) stopped his works because of environmental characteristics, the deliveries of natural pure lumpy fluorspar of mining company «Suran» (Bashkiriya) make no progress. However, from the middle of 2011 the mine Usugli (Uluntuysky deposit, Chita region) started its work and Garsonuysky Ore-Dressing Works started delivery of welding fluorite concentrate. Besides, the deliveries from Mexico and Iran at average market prices were started. The situation with deliveries was improved, however, it can not be accepted as stable.

Electrode plants still have to manufacture solutions of binders (silicate liquid glasses) for their needs on their own. The situation with deliveries of silicate lump was improved. Company «Zaporozhstekloflyus», producing sodium lump, is working stably. Besides the CJSC «Stroitelny Kompleks», being a part of Magnitogorsk Metal Works, the Magnitogorsk plant for manufacture and processing of glass «MagniZa Ltd.» increased its production. Such competition, undoubtedly, has a benefit for the consumer. The lump is supplied in big-bags.

Certain changes occur at the market of ferroalloys [7, 8]. In the production of ferroalloys China is leading (51\% of the world volume), the next is SAR (12\%), Kazakhstan (5.7\%), Ukraine (4.5\%), Russia (3.7\%). Among the materials produced in Russia: $48 \%$ - silicon 
alloys, $30 \%$ - chromium alloys, $16 \%$ - manganese alloys; their main producers are presented in the Table.

The problems of Russia with providing ferromanganese were supposed to be solved by building of the Yenisei Ferroalloy Plant on the base of Usinsky deposit at $11 \mathrm{~km}$ from Krasnoyarsk. However, the final decision about building of this enterprise, considering the environmental factors, was not yet taken (mass protests of people, the movement «Krasnoyarsk against»).

The Urals-Siberian Mining-Metallurgical Company carries out integrated works connected with exploration of Selezensky deposit of manganese ores in Tashtagol region of Kemerovo province. Melting of manganese ferroalloys, in the first turn ferrosilicon manganese, will be carried out at the «Kuznetsk Ferroalloys Ltd.», where plasma furnaces were put into operation.

The increase of volume of ferrosilicon manganese in production of welding consumables, which is characterized, for example, by a low content of phosphorus in the most widespread grade $\mathrm{MnS} 17 \mathrm{~A}$, is challenging. The Russian producer of FeSiMn, the group of ChEMK, is working with imported raw materials (up to $70 \%$ ). The plants of Ukraine (ferroalloys plants of Nikopol, Zaporozhie and Stakhanov) have immense output capacities, however, due to a high cost of electric power, the volume of which in the cost of products exceeds $45 \%$, two latter plants were stopped in December 2012 as those being unprofitable. The capacities of only one Nikopol Plant are seemed to be enough (more than $1 \mathrm{mln} t$ of FeSiMn and 250,000 t of FeMn), but its production does not exceed $25 \mathrm{t}$ of FeSiMn per month. Import of ferroalloys from Bulgaria to Russia sharply increased, but it is supposed to be the products of Indian and Georgian producers. In 2011 FSUE «Prometey» together with «Butkinsky Titan Ltd.» developed and agreed technical conditions on challenging titanium alloys with manganese and ferrotitanium with a number of leading enterprises, which unfortunately did not find industrial application till now. At the same time the problems with quality ferrotitanium were successfully solved with increase of output volumes of the Kluchevsky Plant of Ferroalloys, which has a required experience.

Such is the situation with basic ferroalloys consumed by the electrode manufacturers. It is pleasant also to mention about the stable work of «Meldis-Ferro Ltd.» with increase of volumes of production at accepted prices of the supplier of powders of ferroalloys and metals ready to application in electrode coatings [9].

In spite of the abovementioned problems with raw materials, the Russian producers dominate at the domestic market, but further intensive work is required to keep the positions.

1. Palievskaya, E.A., Sidlin, Z.A. (2009) Problems of raw materials sources for manufacturing of welding consumables. Svarochn. Proizvodstvo, 9, 25-31.

2. Palievskaya, E.A., Sidlin, Z.A. (2010) Problems of raw materials sources for manufacturing of electrodes. Electrode wire. Ibid., 11, 38-40.

3. Zheltkov, A. (2013) Current technologies for manufacturing of hard-alloy drawing dies. MSiS, 10, 22-28.

4. Zhirnova, T.I., Lebedev, N.M. (2002) Ultrasonic technologies and equipment for steel rolling and welding production. In: Proc. of Sci.-Pract. Seminar on Metal Electrodes for Welding and Surfacing (20-22 May, 2002, Sudislavl), 41-44.

5. Brinyuk, M.V., Semenov, S.E. (2001) Improvement of consumer characteristics of welding wire. Svarshchik, 6, 14-15.

6. Marchenko, A.A., Kiselyova, S.P. (2011) About state-of-the-art in production of fluorite designed for welding. In: Proc. of 4th Int. Conf. on Welding Consumables (Krasnodar, 2011), 130-133.

7. Leontiev, L., Sheshukov, O., Kataev, V. (2013) Ferroalloys at the junction of science and production. Metally Evrazii, 5, 24-27.

8. (2013) Ferroalloys. Ambiguous year. Metallurg. Bull., $1 / 2$.

9. Davydov, A.V. (2005) Experience of manufacture of fine powders of different type ferroalloys. In: Arc welding. Materials and quality, 231-233. Magnitogorsk.

Received 29.04.2014 